13 Tamaoki J, Kondo $M$, Takizawa $\mathrm{T}$. Effect of cAMP on ciliary function in rabbit tracheal epithelial cells. $\mathcal{F}$ Appl Physiol 1989;66:1035-9.

14 Tamaoki J, Kondo M, Takizawa T. Adenosine-mediated cyclic AMP-dependent inhibition of ciliary activity in rabbit tracheal epithelium. Am Rev Respir Dis 1989;139:441-5.

15 Wanner A, Sielczak M, Mella JF, Abraham WM. Ciliary responsiveness in allergic and nonallergic airways. f Appl Physiol 1986;60:1967-71.

16 Brooker G, Harper JF, Terasaki WL, Moylan RD. Radioimmunoassay of cyclic AMP and cyclic GMP. Adv Cyclic Nucleotide Res 1979;10:1-33.

17 Lowry OH, Rosenbrough NJ, Farr AL, Randall RJ Protein measurement with the Folin phenol reagent. f Biol Chem 1951;193:265-75.

18 Villalón $M$, Hinds TR, Verdugo $P$. Stimulus-response coupling in mammalian ciliated cells: demonstration of two mechanisms of control for cytosolic $\left[\mathrm{Ca}^{2+}\right]$. Biophys f 1989;56:1255-8.

19 Kobayashi K, Tamaoki J, Sakai N, Chiyotani A, Takizawa $T$. Inhibition of ciliary activity by phorbol esters in rabbit epithelial cells. Lung 1989;167:277-84.

20 Chand N, Pillar J, Diamantis W, Perhach J, Sofia RD.
Inhibition of calcium ionophore (A23187)-stimulated histamine release from rat peritoneal mast cells by azelastine: implication for its mode of action. Eur $f$ Pharmacol 1983;96:227-33.

21 Nakamura T, Nishizawa Y, Sato T, Yamato C. Effect of azelastine on the intracellular $\mathrm{Ca}^{2+}$ mobilization in guinea pig peritoneal macrophages. Eur $\mathcal{F}$ Pharmacol 1988;148:35-41.

22 Akagi M, Mio M, Tanaka K, Kiniwa S. Mechanism of histamine release inhibition induced by azelastine. Pharmacometrics 1983;26:191-8.

23 Satir P. The role of axonemal components in ciliary motility. Comp Biochem Physiol 1989;94A:351-7.

24 Ross SM, Corrison S. Results of an analytical model of mucociliary pumping. $\mathcal{F}$ Appl Physiol 1974;37:333-40.

25 Jackowski JT, Szapfalusi ZS, Wanner DA, Seybold ZS, Sielczak MW, Lauredo IT, et al. Effects of $P$ aeruginosa-derived bacterial products on tracheal ciliary function: role of $\mathrm{O}_{2}$ radicals. $A m f$ Physiol 1991;260:L61-7

26 Berisha H, Foda H, Sakakibara H, Trotz M, Pakbaz H, Said SI. Vasoactive intestinal peptide prevents lung injury due to xanthine/xanthine oxidase. $\mathrm{Am} f \mathrm{Physiol}$ 1990;259:L151-5.

\title{
Adventitia
}

\section{The lung has no parenchyma}

In case this proposition seems too iconoclastic, I will restate it as follows: within the lung there is no tissue that can usefully be identified and named "parenchyma." I have urged for many years that the use of this word in relation to the lung is inappropriate and should be avoided. Avoidance is not difficult. George Simom managed to write an excellent textbook on lung radiology (Principles of chest $x$-ray diagnosis, 3rd edn. Butterworth, London, 1971) without once using the phrase "lung parenchyma". Fifteen years ago I confirmed in a formal study $(\mathrm{Br} \mathcal{F}$ Dis Chest 1978;72:1-12) that the meanings attached to this phrase by physicians and radiologists on both sides of the Atlantic are so varied that it is virtually meaningless. In many instances the word "parenchyma" can be omitted without altering the apparently intended meaning; in others it is necessary to ascertain the sense in which this word is being used. This sense is usually discordant with accepted usages of "parenchyma" in relation to other organs.

How did this verbal confusion arise? In relation to secreting glands or the liver, "parenchyma" refers to tissues composed of cells having functions specific to the organ concerned, as opposed to supporting and vascular tissues; this usage is unequivocal and, I believe, generally accepted. In the lung I suppose the cells that might be considered to be most organ specific are the type II pneumo- cytes, but it would be absurd to call them the lung parenchyma! The function of the lung depends not upon any one type of cell, but upon the structural and functional interaction of elements of its vasculature and airways to bring about orderly gas exchange in the alveoli. In general it seems that what most people mean when they speak of the lung parenchyma is its peripheral gas exchanging part. There is a fairly well defined demarcation at the ends of the terminal bronchioles between the part in which movement of gas is by diffusion both within airspaces and across alveolar membranes, and airways in which it is by ventilatory to and fro movement. It is now agreed that the part of the lung associated with a terminal bronchiole should be called an acinus; thus I think that what is usually meant by the "lung parenchyma" is the pulmonary acini. If you hear or read these words, consider first whether the word "parenchyma" contributes anything; it can often be eliminated without loss of meaning It may be evident from context that the intended reference is to the pulmonary acini, as opposed to the airways. If you do not think that anyone using these words has this meaning in mind, ask what he or she really means.

I recommend that this weasel word be eliminated from discourse concerning the lung.

G SCADDING 